Int. J. Electrochem. Sci., 11 (2016) $6387-6402$

\title{
A Mediated BOD Microsensor Based on Poly(Neutral Red) and Bacteria Modified Interdigited Ultramicroelectrode Array
}

\author{
Jingfang $\mathrm{Hu}^{1, *}$, Guowei Gao ${ }^{1,2}$, Shanhong Xia ${ }^{2}$ \\ ${ }^{1}$ Information Acquisition and Detection Key Laboratory, Beijing Information Science and Technology \\ University, Beijing, China \\ ${ }^{2}$ State Key Laboratory of Transducer Technology, Institute of Electronics, Chinese Academy of \\ Science, Beijing China \\ *E-mail: jfhu@bistu.edu.cn
}

doi: $10.20964 / 2016.07 .07$

Received: 23 March 2016 / Accepted: 12 May 2016 / Published: 4 June 2016

\begin{abstract}
A mediated microsensor for assessing biochemical oxygen demand (BOD) was proposed based on poly(neutral red) (PNR) and Pseudomonas aeruginosa (P. aeruginosa) bacteria modified interdigited ultramicroelectrode array (IUDA). IUDA was fabricated by micro-electro-mechanism system (MEMS) technique. NR was directly electropolymerized on IUDA to form poly(neutral red) (PNR) layer as immobilized mediator. The gram-negative bacteria $P$. aeruginosa was entrapped into polypyrrole (PPy)-alginate matrix by electropolymerization on PNR layer acted as biocatalyst film. The electropolymerization method provided possibility for immobilization of mediator and bacteria on IUDA for mediated BOD measurement. The mediated microsensor can determine BOD value within $20 \mathrm{~min}$ and possesses an analytical linear range from 5 to $100 \mathrm{mg} / \mathrm{L}$, with a limit detection of $3 \mathrm{mg} / \mathrm{L}$. The as-prepared BOD microsensor exhibited good stability, repeatability and anti-interference ability to heavy metal ions of $\mathrm{Cu}^{2+}, \mathrm{Zn}^{2+}, \mathrm{Mn}^{2+}$ and $\mathrm{Fe}^{3+}$. The measurement results of the BOD microsensor method showed a good agreement with those obtained from conventional $\mathrm{BOD}_{5}$ method for real river water samples.
\end{abstract}

Keywords: mediated BOD microsensor; poly(neutral red); polypyrrole-alginate; interdigited ultramicroelectrode array; Pseudomonas aeruginosa bacteria

\section{$\underline{\text { FULL TEXT }}$}

(C) 2016 The Authors. Published by ESG (www.electrochemsci.org). This article is an open access article distributed under the terms and conditions of the Creative Commons Attribution license (http://creativecommons.org/licenses/by/4.0/). 